\title{
A review of the potential health benefits of pine nut oil and its characteristic fatty acid pinolenic acid
}

\author{
Kayin Xie $^{\mathrm{a}^{*}}$, Elizabeth A. Miles ${ }^{\mathrm{a}}$ and Philip C. Calder ${ }^{\mathrm{a}, \mathrm{b}}$ \\ ${ }^{a}$ Human Development and Health Academic Unit, Faculty of Medicine, University of Southampton, \\ Southampton SO16 6YD, United Kingdom \\ and \\ ${ }^{b}$ NIHR Southampton Biomedical Research Centre, University Hospital Southampton NHS \\ Foundation Trust and University of Southampton, Southampton SO16 6YD, United Kingdom \\ *Author for correspondence at: Human Development and Health Academic Unit, Faculty of \\ Medicine, University of Southampton, MP887 Southampton General Hospital, Tremona Road, \\ Southampton SO16 6YD, United Kingdom; Email: 1crfae@hotmail.com
}

Running title: Pine nut oil and pinolenic acid 


\begin{abstract}
Pine nuts contain pinolenic acid (PNLA) which represents $14-19 \%$ of fatty acids present. Here we review research on pine nut oil (PNO) and PNLA from studies performed in vitro, in animal models and in humans. PNLA has anti-inflammatory action and may improve lymphocyte function. PNO and PNLA have favourable effects on appetite control, perhaps by increasing the blood concentrations of key satiety hormones. Less weight gain and fat deposition were observed in mice fed with high fat diets containing PNO. In vitro research demonstrated that PNLA is a potent dual agonist for co-activation of free fatty acid receptor 1 and4, which could enhance glucose-dependent insulin secretion and insulin sensitivity. PNO increased the activity of antioxidant protective enzymes in serum and decreased the concentration of malondialdehyde, an indicator of lipid peroxidation. Thus, PNLA and its parent PNO could be of potential benefit to human health, although this requires further investigation.
\end{abstract}

\title{
KEY WORDS
}

Pinolenic acid; P. koraiensis; P. sibirica; pine nut oil; health 


\section{$1.1 \quad$ INTRODUCTION}

Pine nuts have a range of culinary uses in many parts of the world. Pine nuts come from the Pinus genus and 29 species have been listed as having edible nuts by the Food and Agriculture Organization of the United Nations (FAO) (FAO, 2015). Pine nuts derived from Pinus koraiensis (Korean pine), P. sibirica (Siberian pine), P. pinea (stone pine) and P. gerardiana (chilgoza pine) are most commonly consumed by humans (Destaillats, Cruz-Hernandez, Giuffrida, and Dionisi, 2010). The nuts are usually 9-12 mm long (Zadernowski, Naczk, and Czaplicki, 2009) and have a high oil content (see section 2). The oil is rich in fatty acids including $\Delta 5$-unsaturated polymethylene-interrupted fatty acids ( $\Delta 5$-UPIFAs), which are characteristic of the seeds of gymnosperms and differ from the structure of other polyunsaturated fatty acids (PUFAs). Pinolenic acid (PNLA; all cis-5, -9, -12-18:3) is the major $\Delta 5$-UPIFA in pine nuts and their oil (Wolff and Bayard, 1995). Other $\Delta 5$-UPIFAs in pine nut oils (PNO) are sciadonic acid (all cis-5, -11, -14-20:3) and taxoleic acid (all cis-5, -9-18:2) (Destaillats et al., 2010). The potential influence of PNOs and their characteristic fatty acid constituent, PNLA, on physiological and health related outcomes has been assessed in a number of research studies, mainly performed in vitro and in experimental animals. The aim of this review is for the first time to collate, summarize and discuss the research findings with PNO and PNLA. Only research with Korean or Siberian PNO is considered.

\subsection{DATA SOURCES}

The Pubmed database was accessed in September 2015 to identify relevant studies for this review. The terms used for the search were "Korean pine nut oil", "Siberian pine nut oil", "P. koraiensis", "P. Sibirica" and "pinolenic acid", all separately. Studies about other Pinus genus or those not relevant to health were excluded.

\section{SOURCES AND COMPOSITION OF PINE NUT OILS}

The high demand for pine nuts has lead to an increase in their worldwide production (FAO, 2015). China, Korea, Russia (Siberia) and Pakistan are the main exporting countries of pine nuts (FAO, 2015). Pine nuts have many culinary uses in their own right and the oil may also be extracted and used.

Oil yield depends upon the mode of extraction (e.g. cold pressing, solvent extraction), but is typically reported to be 45 to $65 \mathrm{~g} / 100 \mathrm{~g}$ of nut ( Chen, Zhang, Wang, and Zu, 2011; Ryan, Galvin, O’Connor, Maguire, and O’Brien, 2006; Zadernowski et al., 2009). Oil from P. sibirica is reported 
to be composed of $99.4 \mathrm{wt} \%$ nonpolar lipids and $0.60 \mathrm{wt} \%$ polar lipids (Zadernowski et al., 2009). Triacylglycerols (TAGs) are an important constituent of the nonpolar lipids; Acheampong, Leveque, Tchapla, and Heron (2011) identified 58 different TAG species in the oil of $P$. koraiensis using non-aqueous reversed phase chromatography-electrospray ionization-mass spectrometry with silver nitrate. Because of their high TAG content, pine nuts and PNO have a high content of fatty acids (esterified into TAG). The fatty acids in pine nuts are typically 50\% PUFAs, 40\% monounsaturated fatty acids (MUFAs) and 10\% saturated fatty acids (SFAs) (Ryan et al., 2006). The fatty acid composition of $P$. sibirica and $P$. koraiensis oils determined by several researchers is presented in Table 1. Linoleic acid (all-cis-9-, 12-18:2) is the major PUFA and the most common fatty acid in PNO. Oleic acid (cis-9-18:1) is the dominant MUFA and is the second most abundant fatty acid. PNLA is the most prevalent UPIFA, typically comprising 14 to $19 \mathrm{wt} \%$ of total fatty acids (Table 1). Palmitic acid (16:0) and stearic acid (18:0) represent the major SFAs in PNO (Ryan et al., 2006; Zadernowski et al., 2009). Figure 1 shows a gas chromatogram profile of the fatty acids present in the oil of $P$. sibirica demonstrating the presence and relative abundance of palmitic acid, oleic acid, linoleic acid, and PNLA.The content of PNLA in oil from P. koraiensis has been markedly enriched up to $45 \%$ of fatty acids by Lee, Lee, Lee, Kim, and Rhee (2004) and to >99\% of fatty acids by No et al.(2015) by controlled enzymatic and chemical treatments of the oil.

The peroxide value of oil from $P$. sibirica ranged from 0.26 to 1.00 meq of active $\mathrm{O}_{2} / \mathrm{kg}$ (Zadernowski et al., 2009). Ryan et al. (2006) found a slightly lower result for PNO (species undefined): $0.22 \mathrm{meq} \mathrm{O}_{2} / \mathrm{kg}$. These values show a good stability of unsaturated fatty acids in PNOs to oxidation, perhaps reflecting the presence of antioxidant compounds in the oil. Indeed, phytosterols, tocopherols and squalene are all found in pine nuts and PNOs (Ryan et al., 2006). The content of $\alpha$-tocopherol, $\gamma$-tocopherol and squalene in PNO (species undefined) was reported as 124, 105 and 39 mg/g oil, respectively (Ryan et al., 2006). However, Zadernowski et al. (2009) reported lower amounts of $\alpha$-tocopherol and $\gamma$-tocopherol in P. sibirica oil (25.0-26.7 and 20.2-22.0 $\mathrm{mg} / 100 \mathrm{~g}$ oil, respectively), suggesting that the nuts and oils of different species of Pinus may have different chemical compositions, perhaps reflecting the environment in which they were grown. $\beta$ Sitosterol is the most prevalent phytosterol reported to be present at $1842 \mathrm{mg} / \mathrm{g}$ in PNO (species undefined) (Ryan et al., 2006). Campesterol (215 mg/g oil) and stigmasterol (681 mg/g oil) were present in lower amounts.

Proteins are also an important component of pine nuts. In $P$. pinea nuts 13.08 g protein $/ 100 \mathrm{~g}$ nuts was detected (Venkatachalanand Sathe, 2006). Pine nuts and PNOs also contain a variety of minerals (Zadernowski et al., 2009). 
Table 1: Reported fatty acid compositions of oil from P. sibirica and P. koraiensis. Data are individual fatty acid percentage of total fatty acids.

\begin{tabular}{|c|c|c|c|c|c|c|c|c|}
\hline Authors & Oil & $\begin{array}{l}\text { Extraction } \\
\text { method }\end{array}$ & $\begin{array}{l}\text { Fatty acid } \\
\text { analytical } \\
\text { method }\end{array}$ & PNLA & LA & $\mathrm{OA}$ & SA & PMA \\
\hline $\begin{array}{l}\text { Deineka \& } \\
\text { Deineka, } 2003\end{array}$ & P. sibirica & Acetone & $\begin{array}{l}\text { Reverse- } \\
\text { phase } \\
\text { HPLC }\end{array}$ & 17.0 & 49.0 & 23.8 & 2.5 & 6.3 \\
\hline \multirow[t]{2}{*}{$\begin{array}{l}\text { Zadernowski } \\
\text { et al., } 2009\end{array}$} & P. sibirica & $\begin{array}{l}\text { Cold- } \\
\text { pressing }\end{array}$ & GC & 19.2 & 46.0 & 24.7 & 2.8 & 4.8 \\
\hline & & Hexane & & 18.5 & 46.4 & 24.8 & 2.8 & 4.1 \\
\hline \multirow[t]{2}{*}{$\begin{array}{l}\text { Destaillats et } \\
\text { al., } 2010\end{array}$} & P. sibirica & Hexane & GC & 18.3 & 43.5 & 25.5 & 2.5 & 4.4 \\
\hline & P. koraiensis & & & 14.6 & 45.2 & 27.5 & 2.2 & 4.9 \\
\hline $\begin{array}{l}\text { Asset et al., } \\
1999\end{array}$ & P. koraiensis & $\begin{array}{l}\text { Chloroform- } \\
\text { methanol }\end{array}$ & GC & 14.9 & 48.4 & 25.5 & 1.8 & 4.2 \\
\hline $\begin{array}{l}\text { Wolff \& } \\
\text { Bayard, } 1995\end{array}$ & P. koraiensis & $\begin{array}{l}\text { Chloroform- } \\
\text { methanol }\end{array}$ & GC & 14.9 & 48.4 & 24.1 & 1.8 & 4.2 \\
\hline
\end{tabular}

Abbreviations are: PNLA, pinolenic acid; LA: linoleic acid; OA, oleic acid; SA, stearic acid; PMA, palmitic acid;

HPLC, high-performance liquid chromatography; GC: gas chromatography. 


\section{STRUCTURE, BIOSYNTHESIS AND METABOLISM OF PINOLENIC ACID}

PNLA is typically present at about 14 to $19 \%$ of fatty acids across oils originating from different Pinus species (Table 1). PNLA is a $\Delta 5$-UPIFA and its chemical structure is similar to that of $\gamma$-linolenic acid (GLA; all cis-6, -9, -12-18:3) and $\alpha$-linolenic acid (ALA; all cis-9, 12, -15-18:3). GLA is an n-6 PUFA and is a positional isomer of PNLA. ALA is an n-3 PUFA and is an isomer of GLA (Figure 2).

In mammals GLA is synthesized from linoleic acid (LA; all cis-9, -12-18:2) by $\Delta 6$-desaturase (Kapoor and Huang, 2006). Thereafter, GLA is elongated to dihomo $\gamma$-linolenic acid (DGLA; all cis-8, -11, -14-20:3) by an elongase enzyme (Kapoor and Huang, 2006). The pathway of PNLA synthesis has not been fully established yet. However, the similarity of GLA and PNLA suggests that PNLA may be synthesized from LA by $\Delta 5$-desaturase, because of the different position of the double bond in GLA and PNLA (Kajikawa et al., 2006). However, the $\Delta 5$-desaturase enzyme that is associated with the synthesis have not yet been described in Pinus (Kajikawa,et al. 2006). However, Kajikawa et al.(2006) investigated the microalgae Chlamydomonas reinhardtii for the presence of $\Delta 5$-desaturase genes that could be involved in the synthesis of PNLA from LA. A cDNA clone LCL007g01 was found that contained 3154 base pairs and an open reading frame of 1431 base pairs. This cDNA showed 21\% resemblance to the $\Delta 5$-desaturase gene from Mortierella alpine and was named CrDES. The conserved N-terminal cytochrome $b 5$ domain and the glutamine residue in the third histidine box found in the CrDES amino acid sequence suggest that PNLA synthesis is by front-end desaturation.

The metabolism of PNLA in mammalian systems is not well explored. In rat liver microsomes and human hepatoma HepG2 cells, PNLA was elongated by the fatty acid chain elongation system to $\Delta-7$ eicosatrienoic acid ( $\Delta$-7 ETA; all cis-7, -11, -14-20:3) (Tanaka et al., 1999; Tanaka, Hattori, Kouchi, Hirano, and Satouchi, 1998).

\section{EFFECTS ON INFLAMMATION}

It is widely known that dietary fatty acids can influence the production of lipid and peptide mediators of inflammation (Calder, 2012, 2015a). In general, n-6 PUFAs are substrates for 
the production of pro-inflammatory lipid mediators, whereas n-3 PUFAs result in lower production of n-6 PUFA derived lipid mediators and a range of peptide mediators and are substrates for inflammation resolving lipid mediators (Calder, 2012, 2015a; Galli and Calder, 2009). PNLA also appears to decrease production of pro-inflammatory mediators (Table 2). In murine microglial BV-2 cells stimulated with lipopolysaccharide (LPS), a classic inflammatory stimulus, production of a range of pro-inflammatory mediators was decreased by PNLA (S.-J. Chen, Chuang, Liao, Huang, and Lin, 2015). Incubation of the cells with PNLA at a concentration of $50 \mu \mathrm{M}$ decreased the production of nitric oxide (NO), interleukin (IL)-6 and tumor necrosis factor $\alpha$ (TNF- $\alpha$ ) by 41,74 and $27 \%$, respectively (Chen et al., 2015). A significant decrease in prostaglandin (PG) $E_{2}$ production wasalso observed but further details of this were not provided (Chen et al., 2015). Similar findings were seen when rat primary peritoneal macrophages were used: PNLA decreased production of NO (details not given) and $\mathrm{PGE}_{2}$ (by 35\%) following LPS-stimulation (Chen et al., 2015). Similarly PNLA decreased $\mathrm{PGE}_{2}$ production by LPS-stimulated murine macrophage RAW264.7 cells (Chuang, Tsai, Lee, and Huang, 2009). The effect of PNLA was dose dependent. LPS stimulation of macrophage-type cells induces expression (mRNA and protein) of inducible nitric oxide synthase (iNOS), responsible for increased NO production, and cyclooxygenase-2 (COX-2), responsible for increased $\mathrm{PGE}_{2}$ production. The up-regulation of iNOS and COX-2 gene expression in response to LPS often involves activation of the nuclear factor kappa B (NFkB) pathway.S.-J. Chen et al.(2015) reported downregulation of LPS-induced iNOS (54\%) and COX-2 (11\%) protein expressionby PNLA. This suggests that PNLA may inhibit activation of NFKB, as has been shown for n-3 PUFAs (Calder, 2012, 2015a). However, although Chuang et al. (2009) also reported that PNLA decreased PGE 2 production, they found an increase of COX-2 protein expression (12\%) after incubation of macrophages with PNLA. These findings would suggest that the downregulation of $\mathrm{PGE}_{2}$ is not necessarily accounted for by lower abundance of COX-2, but may be due to the competition ofPNLA and its 20-carbon metabolite $\Delta-7$ ETA with arachidonic acid (AA; all cis-5, -8, -11, -14-20:4) as a substrate for COX-2 (Chuang et al., 2009).

Anti-inflammatory effects of $P$. sibirica oil have been reported in rats injected with carrageenan into the right hind paw, which induces an acute inflammatory response. After 12 and 24 hours, a decrease in oedema formation was seen in rats that had received the PNO orally for a period of time prior to the carrageenan injection (Shikov, Pozharitskaya, Makarov, 
and Makarova, 2008). Application of the PNO directly onto the paw had an antipyretic effect as well. Furthermore, the response time of the rats to exposure of the paw to a hot plate was increased by 1.4 times (Shikov et al., 2008).

\section{EFFECTS ON IMMUNE FUNCTION}

Two animal studies have investigated the effect of including PNO in the diet on immune function (Table 2). In a study by Matsuo et al.(1996) rats were fed with P. koraiensis oil and immunized with intraperitoneal ovalbumin. The proportion of $\mathrm{CD}^{+} \mathrm{T}$-lymphocytes (helper $\mathrm{T}$ cells involved in regulating the immune response) in the spleen and the production of leukotriene $\mathrm{B}_{4}\left(\mathrm{LTB}_{4}\right)$ and immunoglobulin $(\mathrm{Ig}) \mathrm{E}$ and $\mathrm{G}$ by spleen cells were higher in rats that received PNO compared to those that received safflower oil (Matsuo et al., 1996). Park, Lim, Shin, and Han (2013) described greater proliferation of spleen lymphocytes in response

to the T-cell stimulant Con A if the cells came from mice fed PNO. However, a higher dosage of PNO did not show a stronger response. Furthermore, PNO feeding resulted in higher production of IL-1 $\beta$ by LPS-stimulated splenocytes (Park et al., 2013).This effect contrasts with the anti-inflammatory actions of PNLA reported by others (see section 4). This difference could be accounted for by the fact that studies of Chen et al. (2015) and Chuang et al. (2009) used PNLA whereas Park et al. (2013) used PNO. PNO not only contains PNLA but is comprised of nearly $50 \%$ of LA, the precursor of AA. The increased exposure to $n-6$ PUFAs through the diet could have resulted in increases in some inflammatory responses.

\section{EFFECTS ON APPETITE AND BODY WEIGHT}

PNO appears to have beneficial effects on weight gain and appetite control (Table 2). Cholecystokinin (CCK)-8 is a gut hormone that is synthesized in duodenal enteroendocrine cells and promotes digestion of protein and lipid (Burton-Freeman, Davis, and Schneeman, 2004). Glucagon like peptide-1 (GLP-1) is produced in the ileum in response to carbohydrates and fat in the diet (Lavin et al., 1998). Both hormones are responsible for inducing satiety and act to suppress appetite (Degen, Matzinger, Drewe, and Beglinger, 2001; Gutzwiller, Degen, Matzinger, Prestin, \& Beglinger, 2004). P. koraiensis oil was seen to increase CCK-8 secretion by a murine neuroendocrine tumor cell line (STC-1 cells) (Pasman et al., 2008). In 
the study by Pasman et al. (2008) with overweight post-menopausal women circulating CCK8 and GLP-1 concentrations were measured after P. koraiensis free fatty acid (FFA) or TAG or olive oil (as placebo) consumption. After 4 hours the circulating concentration of CCK-8 was higher by 60 and 22\% with PNO FFA and PNO TAG relative to placebo, respectively. For GLP-1 the increase was 25\% higher with PNO FFA compared to placebo (Pasman et al., 2008). Prospective food intake was lowered by $36 \%$ after PNO FFA (Pasman et al., 2008). In a different study, a 9\% attenuated food intake in an ad-libitum lunch buffet after PNO FFA consumption was observed (Hughes et al., 2008). A 9\% reduction in food intake is analogous to a 7\% (or $50 \mathrm{kcal}$ ) decrease in energy intake (Hughes et al., 2008). To put this effect in context, by consuming $50 \mathrm{kcal}$ more than their energy needs a person could see a $1 \mathrm{~kg}$ increase in body weight over a year (Brown, Williams, Ford, Ball, and Dobson, 2005).

Reduced food intake might lead to weight loss or to slower weight gain. This has been studied in animal experiments. In a recent study, mice fed with high-fat diet (HFD) containing PNO had a $17 \%$ lower weight gain than those fed with HFD containing soybean oil (Park et al., 2013). The attenuated weight gain was attributable to reduced adipose tissue deposition in mice receiving PNO. The energy consumption of the mice in the HFD-PNO groups was 4\% less than in the control group (Park et al., 2013). Le et al. (2012) also demonstrated less weight gain in mice fed with HFD-PNO compared with a high soybean oil diet. Genes related to fatty acid oxidation, mitochondrial oxidation and skeletal muscle oxidative metabolism were upregulated by feeding PNO compared with soybean oil (Le et al., 2012).In addition, the expression of the genes specific to type-I skeletal muscle, which has a high oxidative capacity, was increased in the HFD-PNO group. In common with some other PUFAs, PNLA could act as a ligand for peroxisome proliferator activated receptors $\alpha$ and $\delta$ (PPAR $\alpha$ and PPAR $\delta$ ), because it is the positional isomer of GLA (Le et al., 2012). Normally DGLA is the ligand for PPAR $\alpha$ and PPAR $\delta$ (Georgiadi et al., 2010; Lin, Ruuska, Shaw, Dong, and Noy, 1999). These nuclear receptors are associated with oxidative lipid metabolism(Wang, 2010). Uncoupling protein 1 (UCP-1), a key protein in the regulation of thermogenesis, and other genes that induce thermogenesis in brown adipose tissue were also upregulated in mice fed with a HFD containing PNO (Le et al., 2012). Taken together, these observations suggest that PNO has a range of effects that result in reduced food and energy intake (through enhanced production of appetite controlling hormones) and enhanced energy expenditure (through increased oxidative metabolism in key organs and an increase in brown adipose tissue 
thermogenesis). These effects would result in less adipose tissue deposition, less weight gain, less ectopic fat deposition and a more healthy metabolic state.

\section{EFFECTS ON BLOOD LIPIDS}

In rats $P$. koraiensis oil has the potential to lower age-related elevation of blood pressure and to enable better blood cholesterol concentrations compared to safflower oil, although PNO was less effective than flaxseed oil (Sugano, Ikeda, Wakamatsu and Oka, 1994). In liver (HepG2) cells treated with a high PNO fatty acid extract, higher internalization of 3,3'dioctadecylindocarbocyanine low-density-lipoprotein (dil-LDL) was observed (Lee et al., 2004). This suggests that $P$. koraiensis oil has the ability to lower low-density lipoprotein (LDL) through enhancing its hepatic uptake mechanism. Asset et al.(1999) observed lower serum TAG and very-low-density lipoprotein (VLDL)-TAG concentrations in rats fed PNO compared with other oils; however although the effects were quite large, the differences were not statistically significant. Similar, but significant, findings have been reported by ( Chen et al., 2011) with lower serum total TAG levels in rats fed with P. koraiensis oil compared to rats fed with lard. Lowered serum TAG would be consisted with enhanced fatty acid oxidation (see section 6) and/or with increased insulin sensitivity (see section 8).

\section{EFFECTS ON INSULIN SENSITIVITY}

Type 2 diabetes is a metabolic disease that involves insulin resistance (Martin et al., 1992). Fatty acids play a role in activating a family of free fatty acid receptors (FFA1, FFA2, FFA3 and FFA4) in many tissues including those involved in insulin responsiveness (Itoh, Kawamata, and Harada, 2003). Recently PNLA was shown to have a high potency and high efficacy as a ligand for both FFA1 and FFA4 (Calder, 2015b; Christiansen et al., 2015). Activation of FFA1 leads to an increase of glucose-stimulated insulin secretion by pancreatic $\beta$-cells (Briscoe et al., 2003; Itoh et al., 2003), while FFA4 activation leads to enhanced insulin sensitivity (Oh et al, 2011; Stone et al., 2014). In mice administered with PNLA or PNO, blood glucose-lowering effects were seen 30 min after glucose exposure (Christiansen et al., 2015). It seems that co-activation of FFA1 and FFA4 by PNLA could enhance the glucose-dependent insulin secretion and promote efficient glucose disposal. 


\section{EFFECTS ON CANCER METASTASIS}

Some PUFAs, like eicosapentaenoic acid (EPA; all cis-5, -8, -11, -14, -17-20:5), seem to have inhibiting effects on cancer development while others, like AA, seem to promote cancer development (Rose, Connolly, Rayburn, and Coleman, 1995). Chen, Hsu, Li, Lu, and Chuang (2011) investigated the effect of PNLA in human breast cancer cells. Cells supplemented with PNLA had 25\% decreased motility and invasiveness. However, no effect on cell proliferation or cell-matrix adhesion was observed. Incubation of the cells with PNLA changed the cellular PUFA composition. The percentage of AA decreased from 12.6 to $4.9 \%$ relative to control cells ( Chen et al., 2011). As a result of the decreased level of AA, $\mathrm{PGE}_{2}$ synthesis was also affected. Since AA is a precursor of $\mathrm{PGE}_{2}$, a dose-dependent reduction of $\mathrm{PGE}_{2}$ production related to PNLA was demonstrated (Chen et al., 2011). COX-2 expression was reduced in these cells after incubation with PNLA (Chen et al., 2011).

\section{EFFECT ON ANTIOXIDANT PROTECTIVE MECHANISMS}

Antioxidant enzymes play a major role in cell defence against free radical induced damage to macromolecules and cells. These enzymes include superoxide dismutase (SOD) and phospholipid hydroperoxide glutathione peroxidase (GSH-Px). In the study by Chen et al. (2011) rats fed on a diet containing $P$. koraiensis oil showed an elevated activity of SOD and GSH-Px in the serum. Total antioxidant capacity (TAOC) in the serum was higher with PNO than in the HFD-control group. Malondialdehyde (MDA) is an indicator of free radical induced lipid damage. Serum MDA levels were lower in the PNO group ( Chen et al., 2011).

\section{EFFECT OF PNLA IN COMBINATION WITH CONJUGATED LINOLEIC ACID (CLA)}

Conjugated linoleic acids (CLAs) are positional and geometric isomers of LA (Kelly, 2001).Some CLA isomers have been shown to have beneficial effects on cardiovascular diseases (McLeod, LeBlanc, Langille, Mitchell, and Currie, 2004), obesity (House, Cassady, 
Eisen, McIntosh, and Odle, 2005), diabetes (House et al., 2005) and cancer (Belury, 2002). However, CLA isomers may have adverse effects too. For example various CLA isomers decreased the amount of adipose tissue in mice, but this was accompanied with hyperinsulinemia and liver steatosis (Clément et al., 2002; Tsuboyama-Kasaoka et al., 2000). These unfavourable effects were prevented by the combination of CLA and PNLA in mice (Ferramosca, Savy, Conte, and Zara, 2008) suggesting that favourable metabolic effects of PNLA might offset the unfavourable effects of CLA. Furthermore, a 23\% lower bodyweight has been reported in mice fed the combination of PNLA and CLA compared to the CLAgroup. This effect is most likely due to decreased fat accumulation in retroperitoneal tissue and mesenteric adipose tissue with PNLA feeding (Ferramosca et al., 2008). The coadministration of CLA and PNLA also led to a decrease in phospholipids, TAG and cholesterol in the liver, muscles and blood cells. Thus, PNLA is able to prevent the negative metabolic effects of CLA.

\section{SUMMARY AND CONCLUSIONS}

PNO contains the $\triangle 5$-UPIFA PNLA, which comprises 14 to $19 \%$ of fatty acid present in the oil. PNO is also rich in the n-6 PUFA LA and contains several lipid-soluble antioxidants. PNO and PNLA are associated with several health benefits. In this review, we evaluated the potential benefits of PNO and PNLA by bringing together data from studies performed in vitro, in animal models and in humans. PNLA has anti-inflammatory action, suppressing production of pro-inflammatory mediators like NO, IL-6, TNF- $\alpha$ and PGE 2 . The downregulation of $\mathrm{PGE}_{2}$ is due to either reduced COX-2 expression or to the competition of 4-7 ETA, the elongation product of PNLA, with AA. PNLA also appears to improve lymphocyte function. Consuming PNO and PNLA has favourable effects on appetite control,

perhaps by upregulating the satiety hormones CCK-8 and GLP-1. These latter effects were demonstrated in human studies. Additionally, less weight gain has been observed in mice fed with HFDs containing PNO. This is a result of enhanced oxidative metabolism and thermogenesis, which uses fuel sources and results in lower adipose tissue and intramuscular lipid accumulation. Moreover, preliminary data suggested that PNLA could modulate the level of LDL in the bloodstream through promoting hepatic uptake. Furthermore, recent in vitro research demonstrated that PNLA is a potent dual agonist for co-activation of FFA1 and FFA4, which could enhance glucose-dependent insulin secretion and insulin sensitivity. In 
those studies PNLA was superior to all other fatty acids studied including the health promoting marine n-3 PUFAs (Christiansen et al., 2015). Human cancer cells incubated with PNLA showed a reduction of cell motility and cell invasion. This suggests that PNLA may have the ability to inhibit cancer metastasis. In addition, PNO increased the activity of the antioxidant protective enzymes SOD and GSH-Px in serum and decreased the concentration of MDA, an indicator of damaging lipid peroxidation. Interestingly, PNLA is able to preserve the beneficial effects of CLA in mice while preventing the adverse metabolic effects.

Thus, PNLA and its parent PNO could be of potential benefit in improving insulin sensitivity, lowering risk of cardiovascular disease, controlling appetite and reducing body weight and body fat gain. However, most studies have been performed on cell lines or in rodent models with only limited human research. Furthermore, studies of both PNO and PNLA in rodents and in humans have been of short duration and there is no information about the longer term effects. It will be important to conduct well-designed human trials of PNO and PNLA to better identify their effects in humans in order to clarify their roles in improving human health. In this context, it is important to note that human studies have shown that extracts from PNO containing PNLA lower energy intake and increase the blood concentration of satiety hormones (Hughes et al., 2008; Pasman et al., 2008). Effective doses of PNO and PNLA will need to be identified in order to fully understand how the findings from human studies, if positive, can be used in the public health context, and to identify the relative benefits of PNLA in comparison with other bioactive fatty acids like GLA, DGLA, ALA, eicosapentaenoic acid and docosahexaenoic acid.

Although PNLA has biological activity, not all of the effects of PNO may be due to PNLA. As described earlier, pine nuts and PNO contain numerous other, often minor, components with likely biological activity, including phytosterols, tocopherols and squalene. It is important not to overlook the possible contribution of these components to any biological effect described for PNO and it will be important to differentiate effects of PNLA from other components of PNO. 
Table 2: Main effects of PNLA and PNO reported in in vitro and in vivo studies.

\begin{tabular}{|c|c|c|c|c|c|}
\hline Effects on & Exposure & Details & Model & Effects of PNO or PNLA & Authors \\
\hline \multirow[t]{3}{*}{ Inflammation } & PNLA & $\begin{array}{l}50 \mu \mathrm{M} \text { PNLA for } 24 \mathrm{~h} \\
\text { followed by stimulation with } \\
0.1 \mu \mathrm{g} / \mathrm{mlLPS} \text { for } 16 \mathrm{~h}\end{array}$ & $\begin{array}{l}\text { Murine microglial } \\
\text { BV-2 cells and rat } \\
\text { primary peritoneal } \\
\text { macrophages }\end{array}$ & $\begin{array}{l}\text { Decreased production of } \mathrm{NO}, \mathrm{PGE}_{2}, \\
\text { IL- } 6 \text {, and TNF- } \alpha \text {; Decreased } \\
\text { expression of iNOS and COX-2 } \\
\text { protein }\end{array}$ & $\begin{array}{l}\text { S.-J. Chen et } \\
\text { al., } 2015\end{array}$ \\
\hline & PNLA & $\begin{array}{l}12,25,50 \text { or } 100 \mu \mathrm{M} \text { PNLA } \\
\text { for } 24 \mathrm{~h} \text { followed by } \\
\text { stimulation with } 0.1 \mu \mathrm{g} / \mathrm{mlLPS} \\
\text { for } 16 \mathrm{~h}\end{array}$ & $\begin{array}{l}\text { Murine macrophage } \\
\text { RAW264.7 cells }\end{array}$ & $\begin{array}{l}\text { PNLA and its metabolite } \triangle-7 \text { ETA } \\
\text { competed with DGLA and AA as a } \\
\text { substrate for COX-2 leading to } \\
\text { concentration-dependent decreased } \\
\text { production of } \mathrm{PGE}_{1} \text { and } \mathrm{PGE}_{2}\end{array}$ & $\begin{array}{l}\text { Chuang et } \\
\text { al., } 2009\end{array}$ \\
\hline & P. sibirica oil & $\begin{array}{l}300 \mathrm{mg} / \mathrm{kg} \text { bodyweight } \mathrm{PNO} \\
\text { for } 2 \text { days and } 4 \mathrm{~h} \text { prior to } \\
\text { carrageenan injection; then } \\
\text { injection of carrageenan into } \\
\text { the right hind paw; Also } \\
\text { exposure of the paw to a } \\
\text { temperature of } 55^{\circ} \mathrm{C}\end{array}$ & Male Wistar rats & $\begin{array}{l}\text { Reduced oedema formation with } \\
\text { PNO; paw response time to heat } \\
\text { exposure on the hot plate faster with } \\
\text { PNO; PNO had an anti-pyretic effect } \\
\text { when applied directly to the paw }\end{array}$ & $\begin{array}{l}\text { Shikov et al., } \\
2008\end{array}$ \\
\hline $\begin{array}{l}\text { Immune } \\
\text { function }\end{array}$ & $\begin{array}{l}\text { Unspecified } \\
\text { PNO }\end{array}$ & $\begin{array}{l}\text { Six high fat diets ( } 45 \% \text { energy } \\
\text { from fat) for } 12 \text { weeks: } \\
\text { 1) } 10 \% \text { kcal PNO or SBO }+35 \\
\% \mathrm{kcal} \text { lard } \\
\text { 2) } 20 \% \text { kcal PNO or SBO }+25 \\
\% \mathrm{kcal} \text { lard } \\
\text { 3) } 30 \% \text { kcal PNO or SBO }+15 \\
\% \mathrm{kcal} \text { lard. } \\
\text { Then cells collected from the } \\
\text { spleen and stimulated with } 0.5\end{array}$ & Male C57BL/6 mice & $\begin{array}{l}\text { Higher splenocyte proliferative } \\
\text { responses to Con A at } 0.5 \mathrm{mg} / \mathrm{L} \text { in all } \\
\text { groups fed with PNO: effect was not } \\
\text { dose dependant. Higher production } \\
\text { of IL-1 } \beta \text { in response to } 10 \mathrm{mg} / \mathrm{L} \text { of } \\
\text { LPS in the groups fed with PNO. }\end{array}$ & $\begin{array}{l}\text { Park et al., } \\
2013\end{array}$ \\
\hline
\end{tabular}


or $1.5 \mathrm{mg} / \mathrm{L}$ Con A or 5,15 or

$30 \mathrm{mg} / \mathrm{L}$ LPS for $72 \mathrm{~h}$ or with 5

$\mathrm{mg} / \mathrm{L}$ Con A for $48 \mathrm{~h}$ or 10

$\mathrm{mg} / \mathrm{L} \mathrm{LPS}$ for $24 \mathrm{~h}$

\begin{tabular}{|c|c|c|c|c|c|}
\hline & $\begin{array}{l}\text { P. koraiensis } \\
\text { oil }\end{array}$ & $\begin{array}{l}\text { AIN-76 type purified diet } \\
\text { containing } 100 \mathrm{~g} / \mathrm{kg} \text { diet of } \\
\text { PNO or SFO with } \\
\text { immunisation on day } 14 \text { and } 35 \\
\text { with } 10 \mathrm{mg} \text { of intraperitoneal } \\
\text { ovalbumin }\end{array}$ & $\begin{array}{l}\text { Male Brown-Norway } \\
\text { rats }\end{array}$ & $\begin{array}{l}\text { The proportion of } \mathrm{CD}^{+} \mathrm{T} \text { cells in } \\
\text { spleen lymphocytes from the PNO } \\
\text { group was higher compared to the } \\
\text { SFO group; } \\
\text { The splenic production of IgG, IgE } \\
\text { and } \mathrm{LTB}_{4} \text { was higher in the PNO } \\
\text { group than in the SFO group. }\end{array}$ & $\begin{array}{l}\text { Matsuo et } \\
\text { al., } 1996\end{array}$ \\
\hline \multirow[t]{3}{*}{$\begin{array}{l}\text { Appetite and } \\
\text { weight gain }\end{array}$} & $\begin{array}{l}\text { Unspecified } \\
\text { PNO }\end{array}$ & $\begin{array}{l}\text { Six high fat diets }(45 \% \text { energy } \\
\text { from fat) for } 12 \text { weeks: } \\
\text { 1) } 10 \% \text { kcal PNO or SBO }+35 \\
\% \text { kcal lard } \\
\text { 2) } 20 \% \text { kcal PNO or SBO }+25 \\
\% \text { kcal lard } \\
\text { 3) } 30 \% \text { kcal PNO or SBO }+15 \\
\% \text { kcal lard. }\end{array}$ & Male C57BL/6 mice & $\begin{array}{l}\text { Overall, lower energy intake (by 4\%) } \\
\text { with PNO compared with SBO; } 17 \% \\
\text { less body weight gain and less white } \\
\text { adipose tissue in all the PNO groups. } \\
\text { Effect was not dose dependent. }\end{array}$ & $\begin{array}{l}\text { Park et al., } \\
2013\end{array}$ \\
\hline & $\begin{array}{l}\text { P. koraiensis } \\
\text { oil }\end{array}$ & $\begin{array}{l}\text { Two high fat diets for } 12 \\
\text { weeks containing } 15 \% \text { energy } \\
\text { from lard and } 30 \% \text { energy } \\
\text { from PNO or SBO }\end{array}$ & Male C57BL/6 mice & $\begin{array}{l}\text { Less body weight gain and less } \\
\text { intramuscular lipid accumulation in } \\
\text { the PNO group than the SBO group }\end{array}$ & $\begin{array}{l}\text { Le et al., } \\
2012\end{array}$ \\
\hline & $\begin{array}{l}\text { PinnoThin }{ }^{\mathrm{TM}} \\
\text { P. koraiensis } \\
\text { FFA and } \\
\text { TAG } \\
\text { capsules }\end{array}$ & $\begin{array}{l}\text { Six capsules with a total of } 2,4 \\
\text { or } 6 \mathrm{~g} \text { PNO TAG or } 2 \mathrm{~g} \text { PNO } \\
\text { FFA or olive oil (placebo) } \\
\text { given } 30 \text { minutes prior an ad- } \\
\text { libitum lunch }\end{array}$ & $\begin{array}{l}\text { Double blind placebo- } \\
\text { controlled randomised } \\
\text { cross-over counter } \\
\text { balanced design with } \\
42 \text { overweight women }\end{array}$ & $\begin{array}{l}\text { Intake of } 2 \mathrm{~g} \text { PinnoThin }{ }^{\mathrm{TM}} \text { FFA prior } \\
\text { to the lunch reduced food intake by } \\
9 \% \text { compared to the olive oil group }\end{array}$ & $\begin{array}{l}\text { Hughes et } \\
\text { al., } 2008\end{array}$ \\
\hline
\end{tabular}




\begin{tabular}{|c|c|c|c|c|c|}
\hline & $\begin{array}{l}\text { (pressed from } \\
\text { Korean PNO) }\end{array}$ & & $\begin{array}{l}\text { (BMI between } 25-30 \\
\mathrm{~kg} / \mathrm{m}^{2} \text { ) }\end{array}$ & & \\
\hline & $\begin{array}{l}\text { P. koraiensis } \\
\text { oil }\end{array}$ & $50 \mu \mathrm{M}$ PNO for $60 \mathrm{~min}$ & $\begin{array}{l}\text { Murine neuro } \\
\text { endocrine tumour cell } \\
\text { line (STC-1) }\end{array}$ & Increased CCK-8 release & $\begin{array}{l}\text { Pasman et } \\
\text { al., } 2008\end{array}$ \\
\hline & $\begin{array}{l}\text { PinnoThin }{ }^{\mathrm{TM}} \\
\text { P. } \text { koraiensis } \\
\text { oil FFA and } \\
\text { TG capsules }\end{array}$ & $\begin{array}{l}\text { Four capsules with either } 3 \mathrm{~g} \text { of } \\
\text { Korean pine nut FFA, Korean } \\
\text { pine nut TAG or olive oil } \\
\text { (placebo) on three test days. }\end{array}$ & $\begin{array}{l}\text { Randomised, placebo- } \\
\text { controlled, double } \\
\text { blind cross-over trial } \\
\text { with } 25 \text { overweight } \\
\text { post-menopausal } \\
\text { women }(\mathrm{BMI} \text { between } \\
\left.25-30 \mathrm{~kg} / \mathrm{m}^{2}\right)\end{array}$ & $\begin{array}{l}\text { Prospective food intake was } 36 \% \\
\text { lower after pine nut FFA compared } \\
\text { to placebo; Blood CCK- } 8 \text { and GLP-1 } \\
\text { were higher after pine nut FFA and } \\
\text { TAG intake compared to placebo }\end{array}$ & \\
\hline \multirow[t]{3}{*}{ Blood lipids } & $\begin{array}{l}\text { P. koraiensis } \\
\text { oil }\end{array}$ & $\begin{array}{l}\text { Fat-free semi purified diet } \\
\text { supplemented with } 50 \mathrm{~g} / \mathrm{kg} \text { diet } \\
\text { PNO or a mixture with } \\
\text { safflower, oleic-acid enriched } \\
\text { sunflower and linseed oils } \\
\text { (control) for } 4 \text { weeks }\end{array}$ & Male Wistar rats & $\begin{array}{l}\text { Serum TAG and VLDL-TAG lower } \\
\text { by } 16 \text { and } 21 \% \text {, respectively, with } \\
\text { PNO than with control (but } \\
\text { differences not statistically } \\
\text { significant). }\end{array}$ & $\begin{array}{l}\text { Asset et al., } \\
1999\end{array}$ \\
\hline & $\begin{array}{l}P . \\
\text { koraiensisoil }\end{array}$ & $\begin{array}{l}\text { AIN-76 type purified diet } \\
\text { containing } 5 \text { g/kgdiet } \\
\text { cholesterol and either } 100 \\
\text { g/kgdiet PNO, SFO or FSO }\end{array}$ & Sprague-Dawley rats & $\begin{array}{l}\text { PNO resulted in lower blood } \\
\text { cholesterol than SFO but higher than } \\
\text { FSO }\end{array}$ & $\begin{array}{l}\text { Sugano et } \\
\text { al., } 1994\end{array}$ \\
\hline & HPAFAE & $\begin{array}{l}\text { Incubation with } 1 \mathrm{mM} \\
\text { HPAFAE or LPAFAE(control) } \\
\text { for } 2 \mathrm{~h} \text { and then treated with } \\
\text { Dil-LDL }(10-90 \mu \mathrm{g} / \mathrm{ml}) \text { for } 2 \mathrm{~h} \\
\text { at } 4 \text { and } 37^{\circ} \mathrm{C}\end{array}$ & HepG2 cells & $\begin{array}{l}\text { Higher internalization of dil-LDL by } \\
\text { cells exposed to HPAFAE than those } \\
\text { exposed to LPAFAE }\end{array}$ & $\begin{array}{l}\text { Lee et al., } \\
2004\end{array}$ \\
\hline
\end{tabular}




\begin{tabular}{|c|c|c|c|c|c|}
\hline & $\begin{array}{l}\text { P. koraiensis } \\
\text { oil }\end{array}$ & $\begin{array}{l}\text { High fat diet with } 2.0,4.0 \text { or } \\
8.0 \mathrm{~g} / \mathrm{kg} \text { diet per day PNO or } \\
\text { high fat diet with } 88 \mathrm{~g} / \mathrm{kg} \text { lard } \\
\text { or normal control diet for } 4 \\
\text { weeks }\end{array}$ & Wistar rats & $\begin{array}{l}\text { Lower serum TAG concentration } \\
\text { with PNO compared to the high lard } \\
\text { diet. Effect was not dose dependent. }\end{array}$ & $\begin{array}{l}\text { X. Q. Chen } \\
\text { et al., } 2011\end{array}$ \\
\hline $\begin{array}{l}\text { Insulin } \\
\text { sensitivity }\end{array}$ & $\begin{array}{l}\text { PNLA or } \\
\text { PNO }\end{array}$ & $\begin{array}{l}30 \text { minutes prior to an oral } \\
\text { glucose load ( } 3 \mathrm{~g} / \mathrm{kg} \text { body } \\
\text { weight) mice were given PNO } \\
(1 \mathrm{~g} / \mathrm{kg} \text { body weight }), \mathrm{PNLA} \\
(100 \mathrm{mg} / \mathrm{kg} \text { body weight }), \\
\text { ethyl pinolenate }(100 \mathrm{mg} / \mathrm{kg} \\
\text { body weight) or corn oil }(1 \\
\mathrm{g} / \mathrm{kg} \text { body weight }) \text { by gavage. }\end{array}$ & Male C57BL/6 mice & $\begin{array}{l}\text { PNLA and PNO lowered blood } \\
\text { glucose concentrations compared to } \\
\text { corn oil. }\end{array}$ & $\begin{array}{l}\text { Christiansen } \\
\text { et al., } 2015\end{array}$ \\
\hline $\begin{array}{l}\text { Cancer } \\
\text { metastasis }\end{array}$ & $\overline{P \text { PNLA }}$ & $\begin{array}{l}\text { Incubation with PNLA (50 or } \\
100 \mu \mathrm{M}) \text { for } 24 \mathrm{~h} \text { and then } \\
\text { stimulation with TPA ( } 10 \\
\mathrm{ng} / \mathrm{ml}) \text { for } 2,12 \text { or } 24 \mathrm{~h} .\end{array}$ & $\begin{array}{l}\text { Human breast cancer } \\
\text { MDA-MB-231 cells }\end{array}$ & $\begin{array}{l}\text { PNLA suppressed cell invasiveness } \\
\text { and motility. }\end{array}$ & $\begin{array}{l}\text { S.-J. Chen et } \\
\text { al., } 2011\end{array}$ \\
\hline $\begin{array}{l}\text { Antioxidant } \\
\text { protective } \\
\text { mechanisms }\end{array}$ & $\begin{array}{l}\text { P. koraiensis } \\
\text { oil }\end{array}$ & $\begin{array}{l}\text { High fat diet with } 2.0,4.0 \text { or } \\
8.0 \mathrm{~g} / \mathrm{kg} \text { diet per day PNO or } \\
\text { high fat diet with } 88 \mathrm{~g} / \mathrm{kg} \text { lard } \\
\text { or normal control diet for } 4 \\
\text { weeks. }\end{array}$ & Wistar rats & $\begin{array}{l}\text { PNO increased SOD and GSH-Px } \\
\text { activities and TAOC in serum, and } \\
\text { decreased MDA in the serum } \\
\text { compared with the high lard group. }\end{array}$ & $\begin{array}{l}\text { X. Q. Chen } \\
\text { et al., } 2011\end{array}$ \\
\hline
\end{tabular}




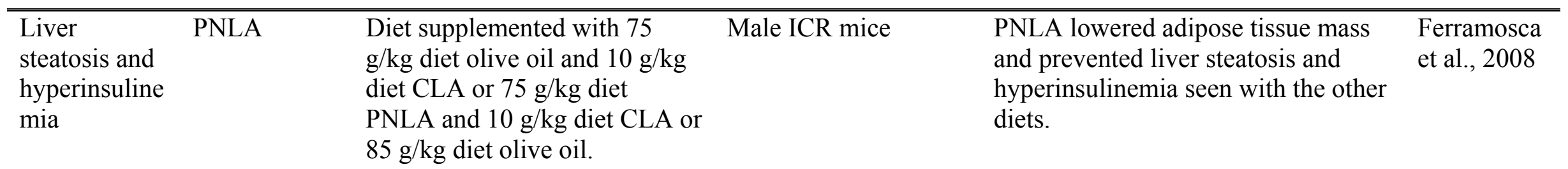

Abbreviations are: PNLA, pinolenic acid; PNO, pine nut oil; LPS, lipopolysaccharide; NO, nitric oxide; PG, prostaglandin; IL, interleukin; TNF- $\alpha$, tumour necrosis factor $\alpha$; iNOS, inducible nitric oxide synthase; COX-2, type-2 cyclooxygenase; $\triangle-7$ ETA, eicosatrienoic acid; DGLA, dihomo $\gamma$-linolenic acid; AA, arachidonic acid; SBO, soybean oil; Con A, concanavalin A; SFO, safflower oil; Ig, immunoglobulin; $\mathrm{LTB}_{4}$, leukotriene B4; FFA, free fatty acid; TAG,triacylglycerol; BMI, body mass index; CCK-8, cholecystokinin 8; GLP-1, glucagon-like peptide-1; VLDL, very-low-density lipoprotein; FSO, flaxseed oil; HPAFAE, high-pinolenic acid-containing fatty acid extract; LPAFAE, low-pinolenic acid-containing fatty acid extract; dil-LDL, 3,3'-dioctadecylindocarbocyanine low-density-lipoprotein; TPA, 12-O-tetradecanoylphorbol 13-acetate; SOD, superoxide dismutase; GSH-Px, phospholipid hydroperoxide glutathione peroxidase; TAOC, total antioxidant capacity; MDA, malondialdehyde and CLA, conjugated linoleic acid- 


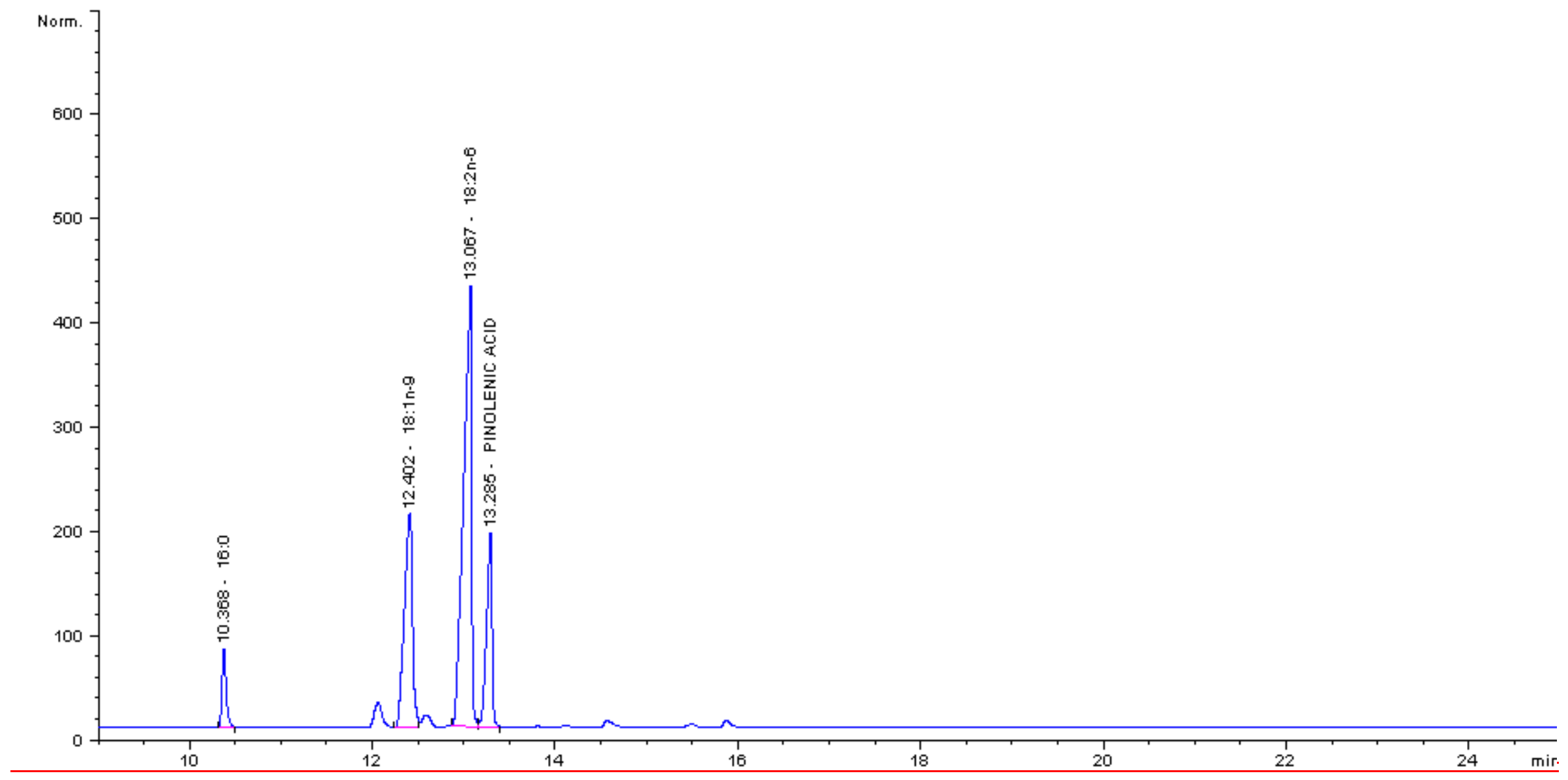

Figure 1: Chromatogram of fatty acid methyl esters derived from P.sibirica oil analysed by gas chromatography. 


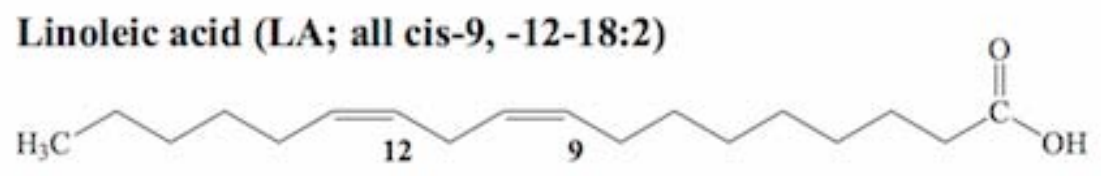

$\alpha$-Linolenic acid (ALA; all cis-9, -12, -15-18:3)

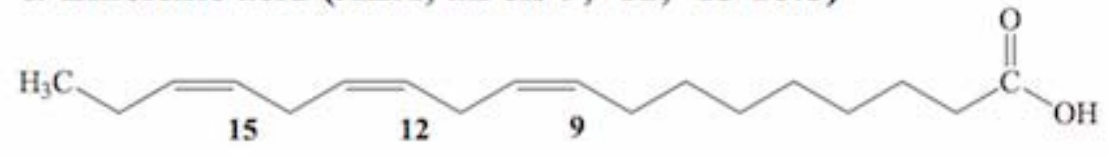

$\gamma$-Linolenic acid (GLA; all cis-6, -9, -12-18:3)

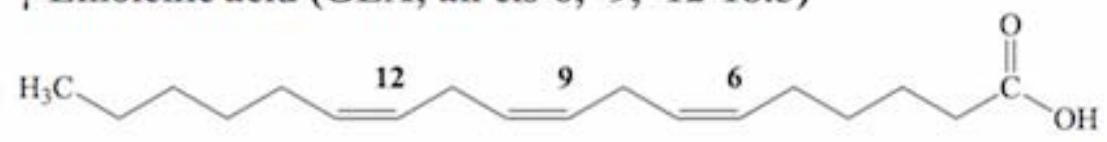

Pinolenic acid (PNLA; all cis-5, -9, -12-18:3)

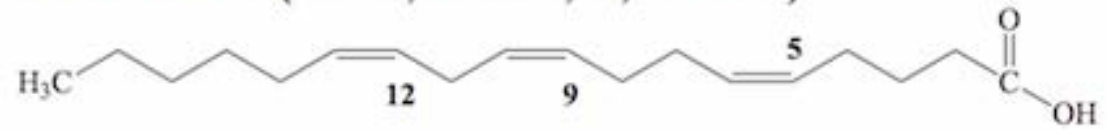

Figure 2: Simple linear structures of linoleic, $\alpha$-linolenic, $\Upsilon$-linolenic and pinolenic acids demonstrating positions of double bonds. 


\section{REFERENCES}

Acheampong, A., Leveque, N., Tchapla, A., and Heron, S. (2011). Simple complementary liquid chromatography and mass spectrometry approaches for the characterization of triacylglycerols in Pinus koraiensis seed oil. Journal of Chromatography A, 1218(31), 5087-5100.

Asset, G., Staels, B., Wolff, R. L., Baugé, E., Madj, Z., Fruchart, J. C., and Dallongeville, J. (1999). Effects of Pinus pinaster and Pinus koraiensis seed oil supplementation on lipoprotein metabolism in the rat. Lipids, 34(1), 39-44.

Belury, M. A. (2002). Inhibition of carcinogenesis by conjugated linoleic acid: potential mechanisms of action. The Journal of Nutrition, 132(10), 2995-2998.

Briscoe, C. P., Tadayyon, M., Andrews, J. L., Benson, W. G., Chambers, J. K., Eilert, M. M., Ellis, C., Elshourbagy, N. A., Goetz, A. S., Minnick, D. T., Murdock, P. R., Sauls, H. R. Jr., Shabon, U., Spinage, L. D., Strum, J. C., Szekeres, P. G., Tan, K. B., Way, J. M., Ignar, D. M., Wilson, S., and Muir, A. I. (2002). The orphan G protein-coupled receptor GPR40 is activated by medium and long chain fatty acids. Journal of Biological Chemistry, 278(13), 11303-11311.

Brown, W. J., Williams, L., Ford, J. H., Ball, K., and Dobson, A. J. (2005). Identifying the energy gap: magnitude and determinants of 5-year weight gain in midage women. Obesity Research, 13(8), 1431-1441.

Burton-Freeman, B., Davis, P. A., and Schneeman, B. O. (2004). Interaction of fat availability and sex on postprandial satiety and cholecystokinin after mixed-food meals. American Journal of Clinical Nutrition, 80(5), 1207-1214.

Calder, P. C. (2012). Omega-3 polyunsaturated fatty acids and inflammatory processes: Nutrition or pharmacology? British Journal of Clinical Pharmacology, 75(3), 645-662.

Calder, P. C. (2015a). Marine omega-3 fatty acids and inflammatory processes: Effects, mechanisms and clinical relevance. Biochimica et Biophysica Acta, 1851(4), 469-484.

Calder, P. C. (2015b). Comment on Christiansen et al.: When food met pharma. British Journal of Nutrition, 114(08), 1109-1110.

Chen, S.-J., Chuang, L.-T., Liao, J.-S., Huang, W.-C., and Lin, H.-H. (2015). Phospholipid incorporation of non-methylene-interrupted fatty acids (NMIFA) in murine microglial BV-2 cells reduces pro-inflammatory mediator production. Inflammation, 38(6), 21332145.

Chen, S.-J., Hsu, C.-P., Li, C.-W., Lu, J.-H., and Chuang, L.-T. (2011). Pinolenic acid inhibits 
human breast cancer MDA-MB-231 cell metastasis in vitro. Food Chemistry, 126(4), $1708-15$.

Chen, X. Q., Zhang, Y., Wang, Z. Y., and Zu, Y. G. (2011). In vivo antioxidant activity of Pinus koraiensis nut oil obtained by optimised supercritical carbon dioxide extraction. Natural Product Research, 25(19), 1807-1816.

Christiansen, E., Watterson, K. R., Stocker, C. J., Sokol, E., Jenkins, L., Simon, K., Grundmann, M., Petersen, R. K., Wargent, E. T., Hudson, B. D., Kostenis, E., Ejsing, C. S., Cawthorne, M. A., Milligan, G., and Ulven, T. (2015). Activity of dietary fatty acids on FFA1 and FFA4 and characterisation of pinolenic acid as a dual FFA1/FFA4 agonist with potential effect against metabolic diseases. The British Journal of Nutrition, 113(11), 1677-1688.

Chuang, L. T., Tsai, P. J., Lee, C. L., and Huang, Y. S. (2009). Uptake and incorporation of pinolenic acid reduces n-6 polyunsaturated fatty acid and downstream prostaglandin formation in murine macrophage. Lipids, 44(3), 217-224.

Clément, L., Poirier, H., Niot, I., Bocher, V., Guerre-Millo, M., Krief, S., Staels, B., \& Besnard, P. (2002). Dietary trans-10,cis-12 conjugated linoleic acid induces hyperinsulinemia and fatty liver in the mouse. Journal of Lipid Research, 43(9), 14001409.

Degen, L., Matzinger, D., Drewe, J., and Beglinger, C. (2001). The effect of cholecystokinin in controlling appetite and food intake in humans. Peptides, 22(8), 1265-9.

Deineka, V. I., and Deineka, L. A. (2003). Triglyceride composition of Pinus sibirica oil. Chemistry of Natural Compounds, 39(2), 126-128.

Destaillats, F., Cruz-Hernandez, C., Giuffrida, F., and Dionisi, F. (2010). Identification of the botanical origin of pine nuts found in food products by gas-liquid chromatography analysis of fatty acid profile. Journal of Agricultural and Food Chemistry, 58(4), 20822087.

FAO. (2015). Food and Agriculture Organization of the United Unions. Chapter 8 Seeds, fruits and cones. <http://www.fao.org/docrep/x0453e/x0453e12.htm> Accessed 5-10-2015.

Ferramosca, A., Savy, V., Conte, L., and Zara, V. (2008). Dietary combination of conjugated linoleic acid (CLA) and pine nut oil prevents CLA-induced fatty liver in mice. Journal of Agricultural and Food Chemistry. 56(17), 8148-8158.

Galli, C., and Calder, P. C. (2009). Effects of fat and fatty acid intake on inflammatory and immune responses: A critical review. Annals of Nutrition and Metabolism, 55(1-3), 123- 
139.

Georgiadi, A., Lichtenstein, L., Degenhardt, T., Boekschoten, M. V, Bilsen, M. V., Desvergne, B., Muller, M., and Kersten, S. (2010). Induction of cardiac Angptl4 by dietary fatty acids is mediated by Peroxisome Proliferator-Activated Receptor $\beta / \delta$ and protects against fatty acid-induced oxidative stress. Circulation Research, 106(11), $1712-1721$.

Gutzwiller, J.-P., Degen, L., Matzinger, D., Prestin, S., and Beglinger, C. (2004). Interaction between GLP-1 and CCK-33 in inhibiting food intake and appetite in men. American Journal of Physiology. Regulatory, Integrative and Comparative Physiology, 287(3), R562-7.

House, R. L., Cassady, J. P., Eisen, E. J., McIntosh, M. K., and Odle, J. (2005). Conjugated linoleic acid evokes de-lipidation through the regulation of genes controlling lipid metabolism in adipose and liver tissue. Obesity Reviews : An Official Journal of the International Association for the Study of Obesity, 6(3), 247-58.

Hughes, G. M., Boyland, E. J., Williams, N. J., Mennen, L., Scott, C., Kirkham, T. C., ... Halford, J. C. (2008). The effect of Korean pine nut oil (PinnoThin) on food intake, feeding behaviour and appetite: a double-blind placebo-controlled trial. Lipids in Health and Disease, 7, 6.

Itoh Y., Kawamata Y., Harada M., Kobayashi M., Fujii R., Fukusumi S., Ogi K., Hosoya M., Tanaka Y., Uejima H., Tanaka H., Maruyama M., Satoh R., Okubo S., Kizawa H., Komatsu H., Matsumura F., Noguchi Y., Shinohara T., Hinuma S., Fujisawa Y., Fujino M. (2003). Free fatty acids regulate insulin secretion from pancreatic beta cells through GPR40. Nature, 1600(2000), 2001-2004.

Kajikawa, M., Yamato K.T., Kohzu Y., Shoji S., Matsui K., Tanaka Y., Sakai Y., Fukuzawa H.(2006). A front-end desaturase from Chlamydomonas reinhardtii produces pinolenic and coniferonic acids by $\omega 13$ desaturation in methylotrophic yeast and tobacco. Plant and Cell Physiology, 47(1), 64-73.

Kapoor, R., and Huang ,Y. S. (2006). Gamma linolenic acid: an antiinflammatory omega-6 fatty acid. Current Pharmaceutical Biotechnology, 7(6), 531-4.

Kelly, G. S. (2001). Conjugated linoleic acid: a review. Alternative Medicine Review : A Journal of Clinical Therapeutic, 6(4), 367-382.

Lavin, J. H., Wittert, G. A., Andrews, J., Yeap, B., Wishart, J. M., Morris, H. A., Morley, J. E., Horowitz, M., and Read, N. W. (1998). Interaction of insulin, glucagon-like peptide 
1, gastric inhibitory polypeptide, and appetite in response to intraduodenal carbohydrate. American Journal of Clinical Nutrition, 68(3), 591-598.

Le, N. H., Shin, S., Tu, T. H., Kim, C.-S., Kang, J.-H., Tsuyoshi, G., Teruo, K., Han, S. N. and Yu, R. (2012). Diet enriched with Korean pine nut oil improves mitochondrial oxidative metabolism in skeletal muscle and brown adipose tissue in diet-induced obesity. Journal of Agricultural and Food Chemistry.60. 11935-11941.

Lee, J.-W., Lee, K.-W., Lee, S.-W., Kim, I.-H., and Rhee, C. (2004). Selective increase in pinolenic acid (all-cis-5,9,12-18:3) in Korean pine nut oil by crystallization and its effect on LDL-receptor activity. Lipids, 39(4), 383-7.

Lin, Q., Ruuska, S. E., Shaw, N. S., Dong, D., and Noy, N. (1999). Ligand selectivity of the peroxisome proliferator-activated receptor alpha. Journal of Controlled Release : Official Journal of the Controlled Release Society, 38(1), 185-190.

Martin, B. C., Warram, J. H., Krolewski, A. S., Soeldner, J. S., Kahn, C. R., Martin, B. C., and Bergman, R. N. (1992). Role of glucose and insulin resistance in development of type 2 diabetes mellitus: results of a 25-year follow-up study. The Lancet, 340(8825), 925-929.

Matsuo, N., Osada, K., Kodama, T., Lim, B. O., Nakao, a, Yamada, K., and Sugano, M. (1996). Effects of gamma-linolenic acid and its positional isomer pinolenic acid on immune parameters of brown-Norway rats. Prostaglandins, Leukotrienes, and Essential Fatty Acids, 55(4), 223-9.

McLeod, R. S., LeBlanc, A. M., Langille, M. A., Mitchell, P. L., and Currie, D. L. (2004). Conjugated linoleic acids, atherosclerosis, and hepatic very-low-density lipoprotein metabolism. American Journal Of Clinical Nutrition, 79(6), 1169S-1174.

No, D. S., Zhao, T. T., Kim, Y., Yoon, M.-R., Lee, J.-S., and Kim, I.-H. (2015). Preparation of highly purified pinolenic acid from pine nut oil using a combination of enzymatic esterification and urea complexation. Food Chemistry, 170, 386-93.

Oh, D. Y., Taluktar, S., Bae, E. J., Imamura, T., Morinaga, H., Fan, W., Li, P., Lu, W. J., Watkins, S. M., and Olefsky, J. M. (2010). GPR120 is an omega-3 fatty acid receptor mediating potent anti-inflammatory and insulin sensitizing effects. Cell, 142(5), 687698.

Park, S., Lim, Y., Shin, S., and Han, S. N. (2013). Impact of Korean pine nut oil on weight gain and immune responses in high-fat diet-induced obese mice. Nutrition Research and Practice, 7(5), 352-8.

Pasman, W. J., Heimerikx, J., Rubingh, C. M., van den Berg, R., O’Shea, M., Gambelli, L., 
... Mennen, L. I. (2008). The effect of Korean pine nut oil on in vitro CCK release, on appetite sensations and on gut hormones in post-menopausal overweight women. Lipids in Health and Disease, 7, 10.

Rose, D. P., Connolly, J. M., Rayburn, J., and Coleman, M. (1995). Influence of diets containing eicosapentaenoic or docosahexaenoic acid on growth and metastasis of breast cancer cells in nude mice. Journal of the National Cancer Institute, 87(8), 587-92.

Ryan, E., Galvin, K., O’Connor, T. P., Maguire, A. R., and O’Brien, N. M. (2006). Fatty acid profile, tocopherol, squalene and phytosterol content of brazil, pecan, pine, pistachio and cashew nuts. International Journal of Food Sciences and Nutrition, 57(3-4), 219-228.

Shikov, A. N., Pozharitskaya, O. N., Makarov, V. G., and Makarova, M. N. (2008). Antiinflammatory effect of Pinus sibirica oil extract in animal models. Journal of Natural Medicines, 62(4), 436-40.

Stone, V. M., Dhayal, S., Brocklehurst, K. J., Lenaghan, C., Sörhede Winzell, M., Hammar, M., Xu, X., Smith, D. M., and Morgan, N. G. (2014). GPR120 (FFAR4) is preferentially expressed in pancreatic delta cells and regulates somatostatin secretion from murine islets of Langerhans. Diabetologia, 57(6), 1182-91.

Sugano, M., Ikeda, I., Wakamatsu, K.and Oka, T. (1994). Influence of Korean pine (Pinus koraiensis)-seed oil containing fatty acid metabolism, eicosanoid production and blood pressure of rats. British Journal Of Nutrition, 72, 175-183.

Tanaka, T., Hattori, T., Kouchi, M., Hirano, K., and Satouchi, K. (1998). Methyleneinterrupted double bond in polyunsaturated fatty acid is an essential structure for metabolism by the fatty acid chain elongation system of rat liver. Biochimica et Biophysica Acta, 1393(2-3), 299-306.

Tanaka, T., Takimoto, T., Morishige, J., Kikuta, Y., Sugiura, T., and Satouchi, K. (1999). Non-methylene-interrupted polyunsaturated fatty acids: effective substitute for arachidonate of phosphatidylinositol. Biochemical and Biophysical Research Communications, 264(3), 683-8.

Tsuboyama-Kasaoka, N., Takahashi, M., Tanemura, K., Kim, H. J., Tange, T., Okuyama, H., Kasai, M., Ikemoto, S., and Ezaki, O. (2000). Conjugated linoleic acid supplementation reduces adipose tissue by apoptosis and develops lipodystrophy in mice. Diabetes, 49(9), $1534-1542$.

Venkatachalan, M., and Sathe, S. K. (2006). Chemical composition of selected edible nut seeds. Journal of Agricultural and Food Chemistry, 54(13), 4705-4714.

Wang, Y.-X. (2010). PPARs: diverse regulators in energy metabolism and metabolic diseases. 
Cell Research, 20(2), 124-37.

Wolff, R. L., and Bayard, C. C. (1995). Fatty acid composition of some pine seed oils. Journal Of The American Oil Chemists' Society, 72(9), 1043-1046.

Zadernowski, R., Naczk, M., and Czaplicki, S. (2009). Chemical composition of Pinus sibirica nut oils. European Journal of Lipid Science and Technology, 111(7), 698-704. 